\title{
MENGKAJI LOGO LG TERHADAP CITRA KONSUMEN
}

\author{
Wahid Nur Wizi ${ }^{1)}$, Royan Fathur Rizki ${ }^{2)}$ \\ Program Studi Desain Komunikasi Visual, \\ Fakultas Bahasa dan Seni, Universitas Indraprasta PGRI \\ Jl. Nangka 58 C Tanjung Barat, Jakarta Selatan, 12530, Indonesia \\ Email:wnwizi36@gmail.com
}

\begin{abstract}
Abstrak
Seiring dengan pesatnya perkembangan teknologi dan perusahaan yang muncul, menjadikan banyak perusahaan bersaing, salah satu cara perusahaan bersaing dengan kompetitornya adalah dengan membuat sebuah logo yang unik, kreatif dan inovatif agar mudah diingat oleh masyarakat. Salah satu perusahaan yang mempunyai logo unik adalah LG. Logo LG sudah terkenal menjadi logo yang sudah melekat dalam hati masyarakat luas. Penelitian ini bertujuan untuk mengkaji makna logo LG terhadap citra pada konsumen. Data diperoleh dari metode analisis desktriptif yang berarti penulisan artikel ini diteliti secara ilmiah dengan mengumpulkan data sekunder seperti artikel atau jurnal yang didapat dari internet dan menggunakan data serta konsep teori yang dianggap berlaku di suatu tempat. Penulisan artikel Makna Logo LG Terhadap Citra Konsumen ini akan menjelaskan seputar citra, dimana citra terhadap konsumen merupakan suatu hal yang penting dan harus diperhatikan, yang merepresentasikan sebuah logo dari produk LG ini. Konsumen memandang arti dari logo LG dan hubungannya dengan rasa konsumen dengan perusahaan LG. LG dengan logonya ingin mempresentasikan perasaan konsumen yang mempercayai mereka sebagai merek yang terpercaya.
\end{abstract}

Kata Kunci: Logo LG, inovasi, dan Citra Merek

\begin{abstract}
As technology develops and many companies emerge, making many companies compete, one way for companies to compete with competitors is to create a unique, creative and innovative logo that is easy for people to remember. One company that has a unique logo is $L G$. The $L G$ logo has been known to be a logo that has been embedded in the hearts of the wider community. This study aims to determine the effect of the meaning of the LG logo on the image of consumers. Data obtained from descriptive analysis method which means writing this article scientifically researched by collecting secondary data such as articles or journals obtained from the internet and using data and theoretical concepts that are considered valid in a place. Writing the article The Meaning of the LG Logo Against Consumer Image will explain about the image, where the image of the consumer is an important thing and must be considered, which represents a logo of this LG product. Consumers look at the meaning of the $L G$ logo and its relationship with the taste of consumers with the $L G$ company. $L G$ with its logo wants to present the feelings of consumers who trust them as a trusted brand.
\end{abstract}

Keywords: Logo LG, Innovation, and Brand image

Correspondence author: Wahid Nur Wizi,wnwizi36@gmail.com, Jakarta, and Indonesia

This work is licensed under a CC-BY-NC 


\section{PENDAHULUAN}

Di dunia bisnis saat ini, semakin banyak persaingan yang pasti harus dihadapi oleh setiap perusahaan, baik itu perusahaan kecil, menengah maupun besar. Setiap perusahaan pasti berlomba-lomba untuk memiliki ciri khas yang menonjol dan dapat menarik perhatian audience. Hal ini sangatlah wajar sebab setiap perusahaan ingin menjadi yang terdepan, terbaik, dan paling dikenal di masyarakat. Selain itu dengan dukungan strategi pemasaran yang baik dan jitu sebuah perusahaan dapat diingat dengan baik oleh audience adalah dengan mempunyai logo yang dirancang dengan baik. Dalam hal ini sebuah logo merupakan perpaduan antara seni dan ilmu yang menyampaikan sebuah janji sebagai wujud dari nilai dan emosi perusahaan tersebut. Perusahaan berusaha untuk menjalin ikatan langsung dengan pelanggannya secara emosional untuk memenuhi kebutuhan pelanggan dan loyalitas serta dukungan yang terus menerus.

Agar perusahaan dapat memperoleh kepercayaan dari masyarakat, akan lebih baik jika perusahaan tersebut dapat mengadopsi sifat-sifat audience yang akan dituju. Sehingga masyarakat merasa bahwa perusahaan ini merupakan perwakilan mereka dan mencerminkan sifat mereka juga. Dan pada akhirnya tercapailah tujuan untuk menjual produk kepada audience. Untuk mencapai semua itu sebuah logo sangat diperlukan untuk dirancang sebaik mungkin karena logo adalah hal pertama yang akan dilihat oleh audience dan kemudian dilanjutkan dengan penampilan produknya. Logo merupakan pencitraan sebuah perusahaan atau dalam istilah lain logo merupakan wajah dari sebuah perusahaan. Logo merupakan suatu yang penting bagi sebuah perusahaan sebagai pengenal dan mempresentasikan identitas dari perusahaan tersebut. Logo merupakan citra dari perusahaan tersebut dan juga sebagai petanda. Perusahaan menciptakan logo mereka sesuai dengan karakter yang mereka punya, logo diciptakan sebagai identitas perusahaan yang menggambarkan kinerja, jenis bidang yang perusahaan itu jalankan, dan untuk mengirimkan pesan terhadap masyarakat tentang perusahaan tersebut, jadi tidak diragukan lagi logo menjadi peran komunikasi yang dapat berdampak pada citra dan penyadaran pada sebuah merek. Sehingga logo menjadi salah satu peran dalam strategi untuk pemasaran. Logo terbagi menjadi tiga jenis yaitu picture mark dan letter mark, picture mark sekaligus letter mark, dan letter mark saja. Salah satu perusahaan yang mempunyai logo yang unik dan menarik adalah perusahaan LG. LG menciptakan logo yang mudah diingat dengan desain yang memiliki keunikan tersendiri dan dapat melekat diingatan orang yang melihat logo tersebut.

Logonya sangat sederhana, ada huruf L dan G di dalamnya. Huruf G menggambarkan wajah dan senyumnya, sedangkan huruf L menggambarkan hidungnya. Slogan LG yang disampaikan saat ini adalah Life's Good untuk lebih mengenalkan huruf L dan G daripada menggunakan kata Lucky Goldstar. Beberapa orang mengatakan bahwa logo LG sangat mirip dengan logo PacMan, karakter salah satu game Nintendo. Itu bisa dilihat jika logo LG diputar 45 derajat. Tetapi bukan berarti LG terinspirasi oleh PacMan (Rochimawati, 2019)

LG adalah perusahaan elektronik terkenal di dunia. Didirikan pada tahun 1958 setelah perang korea. LG Corporation didirikan oleh pengusaha asal Korea Selatan, Koo In-Hwoi. Konglomerasi perusahaan yang berkantor pusat di Yeongdeungpo-gu, Seoul, mengkhususkan diri pada bisnis elektronik, bahan kimia dan produk telekomunikasi.Pada awal mulanya LG bernama GoldStar. Misi utama GoldStar adalah mendorong kemajuan Korea Selatan lewat produksi barang elektronik dalam negeri, Seiring berjalanya waktu, GoldStar merger dengan Lak-Hui Chemical tahun 1995. Keduanya pun mengusung nama baru, yaitu Lucky Goldstar, yang kemudian disingkat menjadi LG. Beroperasi di lebih dari 80 negara di seluruh dunia, perusahaan itu kini mempekerjakan sekitar 220 ribu orang dan memiliki beberapa anak perusahaan. Yaitu, LG Electronics, LG Display, LG Telecom dan LG Chem.

Berbicara tentang logo dan merek, tidak diragukan lagi LG adalah salah satu perusahaan yang paling dikenal di pasar elektronik. Mencerminkan identitas perusahaan yang menyolok dan inovatif, logo yang digunakan terdiri dari huruf L dan G yang membentuk wajah manusia. Kedua huruf itu dikelilingi sebuah lingkaran yang melambangkan dunia, masa depan, pemuda, kemanusiaan, dan teknologi. Tagline Life is Good yang disematkan bersama logo mencerminkan upaya perusahaan tidak kenal lelah untuk membuat pelanggan mereka bahagia. 
Simbol wajah tersenyum mewujudkan keramahan, kepercayaan, dan aksesibilitas, sedangkan titik yang merupakan mata, melambangkan fokus dan orientasi pada tujuan positif perusahaan. Sementara itu, ruang kosong di sisi kanan atas menggambarkan reputasi perusahaan sebagai otoritas terkemuka di dunia dan kemampuan dalam beradaptasi. Penggunaan warna merah di logo LG mewakili gairah, keramahan, dan komitmen perusahaan untuk unggul di bisnis yang digelutinya, sedangkan warna abu-abu mencerminkan teknologi, kecanggihan, dan kehandalan perusahaan. Huruf yang digunakan pada logo itu adalah Helvetica hitam.

Beberapa penelitian tentang logo atau identitas visual sudah pernah dilakukan, di antaranya oleh Violetta dan Melini (2020), penelitian ini menggunakan teori gestal, tetapi fokusnya pada identitas visual yang memiliki distingsi, mudah dikenali, dan mudah diingat. Penelitian yang dilakukan oleh Atsar (2014) juga membahas identitas visual dari logo, tetapi dalam penelitian ini untuk mengetahui persepsi dan citra yang nterbentuk di dalam benak stakeholder atau pelanggan terhadap identitas visual merek logo Bank Mandiri dengan menggunakan angket kuesioner dengan berisikan pernyataan-pernyataan konsep makna bentuk, warna, tipografi dan penampilan keseluruhan logo, dan hasil jawaban pertanyaan angket kuesioner tersebut akan dianalisis secara deskriptif.

Penelitian makna yang terdapat dalam logo LG menggunakan pendekatan teori gestalt dengan pendekatan proximity. Pendeketan proximity, yaitu sebuah kesatuan atau pengelompokan yang terbentuk karena adanya elemen-elemen yang saling berdekatan (Tanudjaja, 2005). Pemaknaan logo juga menggunakan teori warna pada desain, warna dapat mewakili psikologi atau karakteristik sehingga warna bisa mempengaruhi arti sebuah logo. Dalam suatu desain, terutama logo, warna sangat penting karena itu merupakan salah satu elemen yang mampu menarik perhatian orang saat melihat sebuah desain dan menggambarkan makna dari desain tersebut. Warna dalam logo sangat mempengaruhi makna dari logo tersebut, sebuah perusahaan akan memilih warna yang akan mereka tuangkan logo yang berkaitan dengan karakteristik perusahaan mereka agar bisa mempresentasikan sifat perusahaan mereka dari warna-warna yang mereka pilih sebagai identitas mereka.

Tujuan penelitian ini dilakukan untuk membedah logo LG sehingga mendapatkan makna yang ada dalam logo LG tersebut, dan menghubungkan logo tersebut terhadap citra masyarakat. Citra masyarakat sangat mempengaruhi sebuah perusahaan dalam menjalankan bisnisnya, dan citra masyarakat terhadap sebuah logo perusahaan sangat penting karena jika citra masyarakat sesuai dengan apa yang disampaikan logo tersebut maka perusahaan berhasil dalam memperkenalkan identitas mereka.

\section{METODE PENELITIAN}

Artikel ini menggunakan metode kualitatif. Berdasarkan Imam Gunawan, metode kualitatif berusaha memahami dan menafsirkan makna suatu peristiwa interaksi tingkah laku manusia dalam situasi tertentu menurut perpektif peneliti sendiri. Penelitian ini bertujuan untuk memahami obyek yang diteliti secara mendalam. Metode ini bertujuan untuk mengembangkan konsep sensitivitas pada masalah yang dihadapi, menerangkan realitas yang berkaitan dengan penelusuran teori dari bawah (grounded theory) dan mengembangkan pemahaman akan satu atau lebih dari fenomena yang dihadapi (Gunawan, 2013).

Metode ini menggunakan metode analisis desktriptif yang berarti penulisan artikel ini diteliti secara ilmiah dengan mengumpulkan data sekunder seperti artikel atau jurnal yang didapat dari internet dan menggunakan data serta konsep teori yang dianggap berlaku di suatu tempat. Penulisan Artikel Makna Logo LG Terhadap Citra Konsumen ini akan menjelaskan seputar citra, dimana citra terhadap konsumen merupakan suatu Hal yang penting dan harus doperhatikan, yang merepresentasikan sebuah Logo dari produk LG ini. Penulis juga akan memberikan definisi dan ciri-ciri seputar Logo LG, kemudian akan diberikan penjabaran seputar Logo LG terdiri dari ciri-ciri, sejarah, arti Logo, serta penyesuaian Logo LG dapat diterima di Masyarakat diikuti dengan perkembangan teknologi yang sedang dikembangkan oleh LG sehingga tetap bisa berinovasi hingga kini yang dikenal luas tidak hanya di Korea, tetapi juga di berbagai negara lainnya. 


\section{HASIL DAN PEMBAHASAN}

Logo memiliki banyak istilah atau pengertian yang bervariasi. Surianto Rustan (Rustan, 2009) mengungkapkan bahwa logo adalah penyingkatan dari logotype. Istilah logotype ini dikenal lebih dulu dibandingkan kata logo pada tahun 1810 - 1840. Logotype diartikan sebagai tulisan nama entitas yang didesain secara khusus dengan menggunakan jenis huruf tertentu sehingga logotype pada mulanya hanya memuat tulisan saja. Dari waktu ke waktu, logotype terus berkembang menjadi lebih unik dan berbeda. Logotype yang mulanya hanya memuat tulisan, kemudian ditambah dengan elemen gambar yang berbaur menjadi satu dengan tulisan. Hingga pada tahun 1937, istilah logo baru muncul hingga saat ini. Surianto Rustan (Rustan, 2009) juga menjelaskan bahwa logo bisa menggunakan elemen apa saja, seperti tulisan, logogram, gambar dan ilustrasi. Sedangkan kutipan dari Design Institute of Australia, mengungkapkan bahwa logo merupakan sebuah simbol yang digunakan untuk mengidentifikasi perusahaan tanpa adanya kehadiran nama perusahaan. Sebagai sebuah tanda visual, logo seharusnya lebih mudah untuk dikenali daripada tulisan, karena logo berisi mengenai informasiinformasi mengenai produk dan asosiasi produk. Melalui berbagai informasi dan asosiasi produk, logo menjadi sebuah sarana komunikasi untuk lebih mengenalkan atau mendapatkan pengakuan dari masyarakat atas suatu produk atau perusahaan. Menurut Terence A. Shimp, tidak diragukan lagi bahwa logo menjadi peran komunikasi yang dapat berdampak pada citra dan penyadaran pada sebuah merek. Sehingga logo menjadi salah satu peran dalam strategi untuk pemasaran. Namun, (Shimp, 2003) juga menambahkan bahwa pada era ini, strategi yang baik dalam membentuk sebuah logo adalah dengan memilih desain yang tidak terlalu simpel juga tidak terlalu rumit. Melihat dari segi konstruksinya, logo terbagi menjadi tiga jenis, yaitu (a) Picture mark dan letter mark: Elemen gambar dan tulisan saling terpisah, namun tetap dalam satu kesatuan, (b) Picture mark sekaligus letter mark: Elemen gambar dan tulisan saling berbaur sehingga tidak bisa dibedakan mana gambar dan mana tulisan, (c) Letter mark: Hanya terdapat elemen tulisan saja.

Logo merupakan sesuatu yang penting bagi sebuah perusahaan sebagai pengenal dan mempresentasikan identitas dari perusahaan tersebut. Logo merupakan citra dari perusahaan tersebut dan juga sebagai petanda. Logo LG di dalamnya terdiri dari lingkarang dengan huruf L dan $G$ serta titik yang membentuk wajah tersenyum. Warna yang digunakan dalam logo ini adalah merah serta abu-abu pada font logo LG.
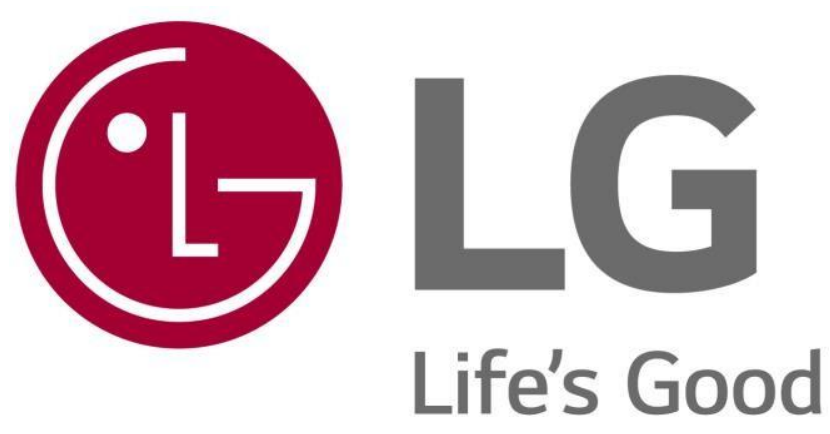

Gambar 1 Logo LG dengan Tagline

Sumber: www.lg.com

Logo pada LG termasuk dalam picture mark sekaligus letter mark dimana huruf dan bentuk titik disatukan dalam sebuah lingkaran dan dibuat berbaur membentuk sebuah wajah sedang tersenyum. Logo LG menggunakan teori gestalt berupa prinsip proximity, yaitu sebuah kesatuan atau pengelompokan yang terbentuk karena adanya elemen-elemen yang saling berdekatan, dengan begitu mata manusia/ konsumen akan membuat seolah elemen itu menjadi kesatuan. Huruf L dan G seolah membuat gambaran orang sedang tersenyum, ditambah degan 
titik yang memperjelas logo tersebut. Hal ini menggambarkan bahwa LG mewujudkan keramahan, kepercayaan, dan aksesibilitas. Titik yang menggambarkan mata, melambangkan fokus dan orientasi pada tujuan positif perusahaan, sementara itu, ruang kosong di sisi kanan atas menggambarkan reputasi perusahaan sebagai otoritas terkemuka di dunia dan kemampuan dalam beradaptasi Huruf "L" dan "G" dalam lingkaran melambangkan dunia, di masa depan, jiwa muda, kemanusiaan, dan teknologi. LG menggambarkan dirinya sebagai perusahaan yang ramah, berteknologi maju dengan segala inovasinya, sehingga masyarakat menjadi percaya dan menggunakan produk LG. Konsumen yang menggunakan produk LG diharapkan puas dan dapat tersenyum juga saat menggunakan produk LG sesuai logo tersebut. Hal itu akan menjadikan konsumen nyaman dan menggambarkan LG sebagai perusahaan besar yang sangat memperhatikan konsumennya yang membuat hubungan LG dengan konsumen terjaga.

Tagline Life is Good yang disematkan bersama logo mencerminkan upaya perusahaan tidak kenal lelah untuk membuat pelanggan mereka bahagia. Simbol wajah tersenyum mewujudkan keramahan, kepercayaan, dan aksesibilitas. Sedangkan titik yang merupakan mata, melambangkan fokus dan orientasi pada tujuan positif perusahaan. Sementara itu, ruang kosong di sisi kanan atas menggambarkan reputasi perusahaan sebagai otoritas terkemuka di dunia dan kemampuan dalam beradaptasi. Tagline tersebut mempunyai arti bahwa LG mengajak konsumen untuk menjadi lebih baik lagi dalam menjalani kehidupan, LG ingin membuat para konsumen merasa hidup lebih baik setelah memakai produk-produk LG dengan kecanggihan teknologinya.

Dalam suatu desain, terutama logo, warna sangat penting karena itu merupakan salah satu elemen yang mampu menarik perhatian orang saat melihat sebuah desain dan menggambarkan makna dari desain tersebut. Warna dapat didefinisikan sebagai sifat cahaya yang dipancarkan, atau secara subjektif/psikologis dari pengalaman indra penglihatan (Monica \& Luzar, 2011). Warna dapat mempengaruhi sisi psikologi seseorang, warna juga memiliki artinya masing-masing, hal itu dikarenakan perasaan yang kita rasakan saat melihat warna tesebut, selain itu juga karena warna tersebut telah digunakan untuk melambangkan sesuatu sehingga warna menjadi identik dengan hal itu. Warna membawa pesan tersendiri bagi orang yang melihatnya, karena dengan warna orang jadi bisa membedakan sesuatu, warna juga memiliki arti yang berbeda menurut kebudayaannya, contoh warna hijau, sering dikaitkan dengan kesuburan, lingkungan, alam, hingga uang, sedangkan di negara-negara Amerika Selatan warna hijau melambangkan kematian. Warna dalam logo sangat mempengaruhi makna dari logo tersebut, sebuah perusahaan akan memilih warna yang akan mereka tuangkan logo yang berkaitan dengan karakteristik perusahaan mereka agar bisa mempresentasikan sifat perusahaan mereka dari warna-warna yang mereka pilih sebagai identitas mereka.

Warna yang dipilih LG untuk logo tersebut adalah warna merah pada lingkaran, dan abu-abu pada tulisan LG serta tagline. Warna merah melambangkan kekuatan, gairah, dan semangat. LG menggunakan warna merah untuk mewakili gairah, keramahan, dan komitmen perusahaan untuk unggul di bisnis yang digelutinya. Dengan menggunakan warna tersebut, LG menggambarkan bahwa LG merupakan perusahaan yang bisa bersaing, bahkan lebih unggul dari kompetitornya, LG memiliki gairah dan komitmen kuat dalam memajukan bisnis dan juga tekonologi dalam setiap produknya agar tetap menjadi unggulan, sehingga konsumen tertarik dan juga menetap pada produk-produk buatan LG. Warna pada font dan tagline menggunakan warna abu-abu. Warna abu-abu melambangkan seimbang, keamanan, masuk akal, klasik, sederhana, dewasa, intelek, keadilan. Warna abu-abu pada logo LG mencerminkan teknologi, kecanggihan, dan kehandalan perusahaan, melambangkan bahwa LG merupakan perusahaan yang bergerak dalam bidang teknologi, seperti TV, smartphone, laptop, hingga prabotan rumah tangga seperti kulkas dan mesin cuci yang berteknologi tinggi. Warna ini juga melambangkan kehandalan perusahaan dalam setiap pemenuhan kebutuhan konsumen dalam bidang teknologi.

Logo sangat mempengaruhi citra merek terhadap masyarakat. Logo adalah salah satu cara sebuah perusahaan untuk memperkenalkan perusahaan/ merek tersebut, dengan memiliki logo yang bisa membuat masyarakat berkesan, itu akan membuat masyarakat mengenal dan mengingat merek kita. Melalui branding yang baik, merek tersebut akan memikat hati 
masyarakat sehingga masyarakat akan tertarik dengan produk yang ditawarkan merek tersebut sehingga meningkatkan penjualan dan menciptakan konsumen-konsumen yang setia menggunakan produk suatu perusahaan.

LG membuat logo tersebut menjadi branding mereka untuk memikat pelanggan. LG menawarkan produk yang berteknologi canggih dan pelayanan yang menarik dan bersahabat seusai yang digambarkan LG dalam logonya. Konsumen juga memandang LG merupakan suatu perusahaan barang elektronik yang berteknologi maju, bersahabat, dan punya produk yang baik dan bagus. Konsumen mendapat ketertarikan akan logo LG yang begitu unik dan mendapatkan kepuasan dalam menggunakan pruduk LG tersebut, sehingga menjadi konsumen setia terhadap produk-produk LG. Menurut pandangan konsumen tersebut, diketahui bahwa LG dengan logonya berhasil membranding mereknya dengan baik, sehingga pesan yang disampaikan LG dalam logo tersebut bisa diterima dan dimengerti oleh konsumen.

Logo LG juga mempresentasikan konsumen mereka yang senang terhadap apa yang mereka dapat dari LG. Konsumen juga menilai LG sebagai produk yang inovatif dan memiliki kualitas tinggi sebagai perusahaan yang bergerak dalam bidang elektronik. Logo LG ingin memberi tahu kepada khalayak ramai jika konsumen yang membeli ataupun berlangganan kepada mereka akan merasakan kepuasan dan senang akan produk-produk yang LG buat, sehingga bisa menarik minat konsumen lain untuk membeli ataupun memakai produk yang LG buat, membuat rasa percaya dan menimbulkan sikap loyalitas konsumen terhadap LG itu sendiri. LG dengan tagline-nya "Life is Good" sebagai acuan kepada khalayak ataupun calon konsumen LG untuk membuat hidup mereka lebih baik, dengan menggunakan teknologi yang memiliki teknologi maju dari LG bisa membuat hidup para konsumennya lebih baik lagi dalam menjalani kehidupan sehari-hari. LG menggambarkan citra konsumen mereka sebagai orang yang sangat senang dan bahagia saat para konsumen sudah mempercayai LG sebagai barang teknologi yang mereka gunakan. LG mengajak semua orang untuk membuat hidup yang lebih baik bersama produk dari LG. LG mempresentasikan citra konsumennya sebagai orang-orang yang bahagia, sudah percaya dan nyaman dan ingin membuat hidup yang lebih baik.

\section{SIMPULAN}

Logo merupakan salah satu bagian terpenting untuk membranding sebuah merek. Dalam sebuah logo terdapat beberapa unsur yang bisa menjadi pengingat bagi siapapun yang melihatnya. Logo yang baik terdiri dari bentuk yang menarik, warna yang digunakan dalam melambangkan merek, dan makna yang terdapat dalam logo tersebut, dengan adanya unsurunsur itu konsumen dapat mengenali sebuah merek dengan melihat logo tersebut, selain itu juga menjadi alat untuk membranding merek tersebut ditambah dengan sebuah tagline yang mempresentasikan tujuan LG. Logo yang dipakai LG memiliki itu semua, dengan gabungan bentuk yang unik dan warna yang menarik, membuat makna logo LG bisa dimengerti oleh orang yang melihat logo tersebut. Hal itu membuat konsumen tertarik dan mengenali perusahaan atau merek LG. Logo tesebut juga mempresentasikan konsumen mereka yang senang dengan pelayanan yang diberikan oleh LG sebagai perusahaan penyedia kebutuhan konsumen khususnya dibidang elektronik. Konsumen menjadi puas dan menjadi percaya dengan apa yang diberikan LG dalam setiap produknya. LG mempresentasikan konsumen mereka sebagai orang yang senang akan produk LG ditambah dengan tagline-nya "Life is Good" mengajak semua orang berubah membuat hidup mereka menjadi lebih baik lagi dengan produk- produk LG.

\section{DAFTAR PUSTAKA}

Atsar, F. (2014). Persepsi dan citra identitas visual logo Bank Mandiri. Jurnal Rekarupa, 2(1).

Gunawan, I. (2013). Metode penelitian kualitatif. Jakarta: Bumi Aksara.

Logo LG. Diakses dari https://www.lg.com/id 
Rochimawati, R. P. (2019, Januari Senin). viva.co.id. From viva.co.id: https://www.viva.co.id/gaya-hidup/inspirasi-unik/1 107846-pesan-tersembunyi-di-baliklogo-logo-ternama?page=all\&utm_medium=all-page

Rustan, S. (2009). Mendesain logo. Jakarta: PT Gramedia Pustaka Utama.

Shimp, T. A. (2003). Periklanan promosi aspek tambahan komunikasi pemasaran terpadu. Jakarta: Penerbit Erlangga.

Tanudjaja, B. B. (2005). Aplikasi prinsip gestalt pada media desain komunikasi visual. Nirmana, 56-66.

Violetta, F., \& Melini, E. (2020). Analisis identitas visual Water Boom Lippo Cikarang. SENADA: Seminar Nasional Desain Dan Arsitektur, 3. 257-263). 